Website: http://e-journal.hamzanwadi.ac.id/index.php/gdk

\title{
(\&EODIKA
}

Terakreditasi S4 - SK No. 36/E/KPT/2019

Penerbit: Program Studi Pendidikan Geografi, FISE, Universitas Hamzanwadi

\section{ANALISIS KEMAMPUAN LITERASI INFORMASI SISWA PADA SISTEM PEMBELAJARAN DARING MATA PELAJARAN GEOGRAFI}

\author{
Muthia Kusuma Insani', Siti Hadiyati Nur Hafida ${ }^{2 *}$ \\ 1,2Pendidikan Geografi, Fakultas Keguruan dan Ilmu Pendidikan, Universitas Muhammadiyah Surakarta, Surakarta, Indonesia \\ *Email Koresponden: shnh421@ums.ac.id
}

Diterima: 01-02-2021, Revisi: 20-05-2021, Disetujui: 06-06-2021

(C)2021 Program Studi Pendidikan Geografi, FISE, Universitas Hamzanwadi

\begin{abstract}
Abstrak Ilmu pengetahuan dan teknologi terus berkembang pesat dalam aspek kehidupan manusia, termasuk dalam bidang pendidikan. Ancaman dampak negatif teknologi informasi menuntut pentingnya literasi informasi siswa dalam mengahadapi beragam informasi yang diterima. Kompetensi literasi informasi yang perlu diperhatikan yaitu: prospecting (mencari), interpreting (menafsirkan), dan creating new idea (menciptakan ide baru). Tujuan dalam penelitian ini yaitu menganalisis hubungan antara ketiga kompetensi literasi informasi siswa selama proses pembelajaran di masa pandemi Covid-19. Jenis penelitian ini yaitu Penelitian Kuantitatif. Jumlah sampel dalam penelitian ini yaitu 67 responden dan teknik sampling yang digunakan yaitu simple random sampling. Hasil penelitian ini menunjukkan: 1) siswa memiliki kemampuan literasi informasi prospecting dengan nilai rata-rata 75,95\% termasuk dalam kategori baik, 2) nilai rata-rata siswa pada kemampuan literasi informasi interpreting yaitu $73,36 \%$, 3) nilai rata-rata siswa pada kemampuan literasi informasi creating new idea yaitu $71,80 \%$ termasuk dalam kategori baik, dan 4) nilai signifikan uji korelasi hubungan antar variabel yaitu 0,000, menunjukkan terdapat hubungan positif antara variabel prospecting, interpreting, dan creating new idea dengan keeratan korelasi yaitu 0,613 yang termasuk kategori kuat. Kesimpulan dalam penelitian ini yaitu kemampuan literasi informasi siswa kelas XI IPS termasuk dalam kategori baik dan terdapat hubungan antara variabel tersebut.
\end{abstract}

Kata kunci: kemampuan literasi informasi, pembelajaran daring, pembelajaran geografi

\begin{abstract}
Science and technology continues to grow rapidly in aspects of human life, including in the field of education. The threat of negative impact of information technology demands the importance of students' information literacy in dealing with various information received. Information literacy competencies that need to be considered are: prospecting, interpreting, and creating new ideas. The aim of this study is to analyze the relationship between the three information literacy competencies of students during the learning process during the Covid-19 pandemic. This type of research is Quantitative Research. The number of samples in this study were 67 respondents and the sampling technique used was simple random sampling. The results of this study indicate: 1) students have prospecting information literacy skills with an average value of $75.95 \%$ included in the good category, 2) the average value of students on interpreting information literacy skills is $73.36 \%$,3) the average score the average student's information literacy ability of creating new idea is $71.80 \%$ included in the good category, and 4) the significant value of the correlation test between variables is 0.000 , indicating that there is a positive relationship between the variables prospecting, interpreting, and creating new ideas with a close correlation, namely 0.613 which is included in the strong category. The conclusion in this study is that the information literacy skills of class XI IPS students are included in the good category and there is a relationship between these variables.
\end{abstract}

Keywords: information literacy competencies, online learning, geography learning

\section{PENDAHULUAN}

Perkembangan Ilmu Pengetahuan dan Teknologi (IPTEK)dengan cepat merambat hampir pada seluruh aspek kehidupan manusia, termasuk dalam bidang pendidikan. Era digitalisasi saat ini memerlukan Sumber Daya Manusia (SDM) yang mempunyai kemampuan berpikir kritis, analitis, imajinatif, dan kemauan untuk bekerjasama serta budi pekerti yang baik (Khoirudin et al., 2017). 
Berkembangnya teknologi informasi mendorong pihak sekolah untuk mampu mengikuti dan menyesuaikan diri. Pendidikan pada akhirnya akan mengalami perubahan akibat adanya perkembangan IPTEK, salah satunya terkait dengan kemampuan literasi informasi sebagai dasar dalam pembelajaran sepanjang hayat.

Literasi informasi terdiri dari dua kata, yaitu literasi dan informasi. Makna dari kata literasi yaitu orang yang melek huruf dan melakukan kegiatan seperti membaca dan menulis, sedangkan informasi berarti wawasan dan pengetahuan yang telah melewati proses pemikiran kemudian dijadikan pembelajaran (Treyani, 2017). Kemampuan mengakses dan menemukan informasi menjadi salah satu faktor penting untuk mengembangkan pembelajaran secara efektif dan efisien (Sinurat \& Amtarina, 2017). Pengelolaan informasi yang baik dan benar adalah sebuah proses pembelajaran seumur hidup (life long education), dengan melakukan pembelajaran seumur hidup pencari informasi akan terus ter-update pengetahuan dan keterampilannya (Suharto, 2014). Terdapat tiga kompetensi yang perlu diperhatikan dalam literasi informasi, yaitu: 1) pencarian, kemampuan untuk menemukan informasi yang relevan, untuk menyaringnya, menyortirnya, dan memilihnya; 2) menafsirkan, kemampuan untuk menerjemahkan data dan informasi menjadi pengetahuan, wawasan, dan pemahaman; dan 3) menciptakan ide baru, mengembangkan wawasan baru (Lau, 2006). Seiring berjalannya waktu, teknologi terus berkembang dan menyebabkan munculnya ledakan informasi, sehingga meningkatnya kesulitan dalam mengakses informasi yang akurat. Perkembangan teknologi juga menyebabkan adanya perubahan atau inovasi baru terhadap sistem pembelajaran yaitu untuk meningkatkan pembelajaran yang lebih kreatif dan memberikan pengalaman baru saat pembelajaran kepada siswa.

Sistem pembelajaran sekolah dapat dilakukan melalui daring (dalam jaringan). Pembelajaran daring adalah salah satu strategi pembelajaran online atau dilakukan melalui jaringan internet (Mustofa et al., 2019). Pembelajaran daring menurut Kemenristekdikti (2017) adalah pembelajaran dalam jaringan melalui jaringan online yang tersambung pada komputer. Sistem pembelajaran daring ini mendukung kemampuan guru dan siswa dalam penggunaan dan pemanfaatan teknologi, namun terdapat beberapa kekurangan pembelajaran daring yaitu: mengharuskan disiplin diri untuk mengikuti kursus pembelajaran daring, perasaan terisolasi, terbatasnya dampak pembelajaran sebaya, kecepatan dan biaya akses internet, dan terkadang membutuhkan biaya awal yang tinggi (perancangan dan peralatan) (Cara \& Chatani, 2019). Sistem pembelajaran daring sekarang ini sedang massif dilakukan oleh semua jenjang pendidikan. Hal tersebut dikarenakan adanya kebijakan WFH (Work From Home) dan SFH (Study From Home) akibat pandemi Coronavirus Disease (Covid-19).

Pembelajaran daring selama pandemi Covid-19 menguji kreativitas dan kemandirian siswa dalam menyelesaikan semua tugas yang diberikan guru. Pembelajaran daring apabila digunakan dengan tepat akan memiliki potensi untuk memberdayakan dan mengubah pembelajar pasif menjadi pembelajar aktif dan mandiri (Cara \& Chatani, 2019). Pembelajaran daring dapat diterapkan untuk semua mata pelajaran, termasuk pada mata pelajaran geografi. Geografi adalah bagian dari ilmu kebumian yang mengkaji secara komprehensif fenomena-fenomena yang ada di permukaan bumi dan hubungan saling tindak dengan kehidupan manusia melalui tiga pendekatan, yaitu : keruangan, temporal, dan kompleks wilayah (Sartohadi et al., 2012). Semua gejala yang ada di permukaan bumi meliputi aspek fisik dan sosial sangat berpengaruh terhadap proses fenomena permukaan bumi (Sholeh, 2007). Materi dalam geografi merupakan salah satu pembelajaran sepanjang hayat bagi siswa, karena materi ini mempelajari bagaimana keadaan lingkungan sekitar dan kesadaran siswa untuk mencintai lingkungan sekitar.

Akibat tranformasi sistem pembelajaran daring, hampir seluruh guru dari berbagai macam tingkat sekolah memberikan tugas yang cukup banyak. Arifa (2020), menyatakan bahwa sistem pembelajaran daring memberikan dampak, seperti: pertama, tugas yang diberikan guru terlalu berat dengan waktu terbatas, kedua tugas merangkum buku mendominasi. Hal ini menjadikan pembelajaran menjadi tidak efektif serta mampu memberikan efek stres, sehingga siswa merasakan kesulitan untuk menyelesaikan tugasnya. Sebagaimana Komisi Perlindungan Anak Indonesia (KPAI) yang menyatakan bahwa penggunaan pembelajaran daring di rumah tidak efektif lantaran banyak guru yang salah konsep mengenai pembelajaran daring dengan memberikan banyak tugas (KPAI, 2020). Penggunaan pembelajaran daring ini tidaklah ideal, karena dapat menyebabkan kehilangan waktu belajar siswa untuk di sekolah, sehingga mengakibatkan kesempatan siswa untuk memperoleh pengetahuan secara langsung 
dari guru menurun (Animar \& Wulandya, 2020). Kondisi ini mendorong peneliti untuk menganalisis literasi informasi siswa selama pembelajaran daring.

Adanya perubahan sistem pembelajaran tatap muka menjadi pembelajaran daring pada akhirnya mendorong peneliti untuk melakukan penelitian Madrasah Aliyah Negeri (MAN) 1 Karanganyar. Terutama terkait dengan sistem pembelajaran daring yang diterapkan di sekolah tersebut. Adapun Tujuan dari penelitian ini adalah untuk menganalisis hubungan antara ketiga kompetensi literasi informasi (prospecting, interpreting, dan creating new idea) siswa selama proses pembelajaran di masa pandemi Covid-19.

\section{METODE PENELITIAN}

Penelitian ini menggunakan metode penelitian kuantitatif. Menurut Donmoyer (2008), penelitian kuantitatif mengacu pada pendekatan untuk penyelidikan empiris yang mengumpulkan, menganalisis, dan menampilkan data dalam bentuk numerik (angka) daripada naratif (kalimat). Penelitian ini dilakukan di MAN 1 Karanganyar dengan alamat lengkap di Jalan Ngalian no. 4, Kelurahan Tegalgede, Kecamatan Karanganyar, Kabupaten Karanganyar. Lokasi penelitian ini didasarkan pada visi MAN 1 Karanganyar yang membentuk siswa untuk berwawasan global, sehingga peran siswa dalam era globalisasi ini sangat penting.

Desain penelitian yang digunakan dalam penelitian ini adalah penelitian korelasional. Penelitian korelasional merupakan penelitian yang menggunakan analisis statistik untuk mengetahui korelasi atau hubungan atau adanya keterkaitan antar variabel. Penelitian kuantitatif korelasional dalam penelitian bertujuan untuk menganalisis adanya hubungan antara variabel independen yaitu tiga kompetensi literasi informasi (prospecting, interpreting, dan creating new idea) dan variabel dependen yaitu kemampuan literasi informasi siswa. Populasi penelitian ini adalah siswa kelas XI IPS MAN 1 Karanganyar dengan jumlah keseluruhan yaitu 204 siswa. Sampel yang digunakan terdiri dari 67 siswa yang telah diukur menggunakan rumus Slovin. Teknik pengambilan sampel dalam penelitian ini menggunakan simple random sampling. Data yang digunakan adalah data sekunder yaitu melalui kuesioner siswa dan dokumentasi data sekolah.

Pengumpulan data dalam penelitian ini menggunakan kuesioner yang disebarkan kepada siswa yang menjadi sampel pada penelitian ini. Jenis kuesioner yang digunakan adalah kuesioner tertutup yang tersaji dalam daftar pertanyaan dengan pilihan jawaban menggunakan skala Likert dengan lima kategori yaitu: a) SS = Sangat Setuju (bobot = 5), b) $S=$ Setuju (bobot = 4), c) RG = Ragu-ragu (bobot = 3), d) TS $=$ Tidak Setuju (bobot $=2$ ), e) STS = Sangat Tidak Setuju (bobot =1). Kuesioner disebarkan secara online menggunakan Google Form. Jenis alat analisis yang digunakan dalam penelitian ini yaitu menggunakan uji korelasi Spearman Rank. Uji Korelasi Spearman Rank dilakukan menggunakan sofware IBM SPSS Statistics 24. Tingkat kepercayaan dalam pengujian hipotesis yang digunakan dalam penelitian ini adalah 95\% atau $(\mathbf{a})=0,05$. Berikut kriteria interpretasi skor pada Tabel 1 .

Tabel 1. Kriteria Interpretasi Skor

\begin{tabular}{cc}
\hline Skor & Kategori \\
\hline $81 \%-100 \%$ & Sangat Baik \\
$61 \%-80 \%$ & Baik \\
$41 \%-60 \%$ & Cukup \\
$21 \%-40 \%$ & Tidak Baik \\
$0 \%-20 \%$ & Sangat Tidak Baik \\
\hline Sumber: (Riduwan \& Sunarto, 2011)
\end{tabular}

\section{TEMUAN DAN PEMBAHASAN}

Hasil temuan dan pembahasan dalam penelitian ini bertujuan untuk mencapai tujuan penelitian. Untuk menganalisis kompetensi literasi informasi terdapat tiga variabel yaitu: 1) literasi informasi Prospecting, 2) literasi informasi interpreting, dan 3) literasi informasi creating new idea, serta 4) hubungan antara ketiga literasi informasi tersebut. 


\section{Literasi Informasi Prospecting (pencarian)}

Tabel 2. Hasil Kuesioner pada Variabel Prospecting

\begin{tabular}{|c|c|c|}
\hline \multirow{2}{*}{ No } & Pertanyaan & \multirow{2}{*}{ Skor $(\%)$} \\
\hline & Prospecting (pencarian) & \\
\hline 1 & $\begin{array}{l}\text { Saya mampu menentukan topik sendiri dalam mencari informasi sesuai dengan tugas yang } \\
\text { diberikan guru }\end{array}$ & $74,62 \%$ \\
\hline 2 & Saya mampu membedakan informasi sesuai dengan kebutuhan saya & $81,79 \%$ \\
\hline 3 & Saya mampu memilih informasi yang akurat & $75,22 \%$ \\
\hline 4 & Saya mampu mencari materi geografi melalui sumber peta, globe, dsb. & $70,14 \%$ \\
\hline 5 & $\begin{array}{l}\text { Saya mampu membuat pertanyaan terlebih dahulu untuk mendapatkan informasi yang } \\
\text { dibutuhkan }\end{array}$ & $72,23 \%$ \\
\hline 6 & $\begin{array}{l}\text { Informasi yang saya dapatkan telah tersedia di buku pelajaran, buku catatan, buku lain } \\
\text { seperti LKS (Lembar Kerja Sekolah), serta sumber referensi lain }\end{array}$ & $78,80 \%$ \\
\hline 7 & Saya dapat memilih sumber informasi di internet yang akurat & $82,38 \%$ \\
\hline 8 & Saya mampu menentukan kata kunci sesuai dengan informasi yang saya butuhkan & $82,38 \%$ \\
\hline 9 & $\begin{array}{l}\text { Saya mampu menyelesaikan tugas individu saya secara mandiri dan tidak langsung } \\
\text { mencontek jawaban teman }\end{array}$ & $69,85 \%$ \\
\hline 10 & $\begin{array}{l}\text { Saya tidak langsung menyalin, menjiplak, atau copy-paste informasi yang saya dapatkan } \\
\text { melalui internet atau sumber lainnya }\end{array}$ & $77,01 \%$ \\
\hline \multirow[t]{3}{*}{11} & $\begin{array}{l}\text { Saya memperhatikan tahun pembuatan informasi, sehingga saya dapat update informasi } \\
\text { terbaru }\end{array}$ & $71,04 \%$ \\
\hline & Jumlah & $835,46 \%$ \\
\hline & Skor Rata-Rata & 75,95\% (BAIK) \\
\hline
\end{tabular}

Sumber: Hasil olahan data primer, 2020.

Skor tertinggi pada kompetensi pertama yaitu prospecting (pencarian) informasi terdapat pada pertanyaan nomor 7 dan 8 yaitu siswa mampu memilih sumber informasi di internet yang akurat dan siswa mampu menentukan kata kunci sesuai dengan informasi yang dibutuhkan dengan hasil skor $82,38 \%$. Angka tersebut berada pada interval 81\% - 100\% kriteria interpretasi skor, artinya skor pada kompetensi literasi informasi ini sangat baik. Siswa telah memahami dalam memilah sumber informasi di internet dengan akurat dan siswa telah memahami kata kunci pertama apa yang harus dicari sesuai informasi yang dibutuhkan pada kebutuhan tugas. Skor terendah pada kompetensi prospecting terdapat pada pertanyaan nomor 9 yaitu siswa mampu menyelesaikan tugas individu secara mandiri dan tidak langsung mencontek jawaban teman dengan hasil skor $69,85 \%$ berada pada interval $61 \%-80 \%$, artinya skor pada kompetensi literasi informasi ini masuk dalam kategori baik, meskipun skor terendah, akan tetapi skor ini telah masuk dalam interpretasi skor baik.

Jumlah skor rata-rata pada kemampuan literasi informasi prospecting memperoleh nilai 75,95\% yang masuk dalam kategori baik. Penelitian ini sejalan dengan penelitian yang dilakukan oleh Treyani (2017), menyatakan bahwa kemampuan literasi informasi sangat penting di era kemajuan teknologi ini yang sedang berkembang, ledakan informasi menyebabkan manusia untuk mengembangkan kemampuan literasi informasi yang dimiliki, selain itu kemampuan literasi informasi siswa dalam mencari informasi yang akurat diperlukan ketika siswa memilih, menentukan, dan menggunakan informasi sesuai dengan kebutuhan. Hasil penelitian ini juga sejalan dengan penelitian yang dilakukan oleh Riani (2017), bahwa kecakapan dalam mencari dan mengidentifikasi informasi sangat diperlukan, karena informasi akan menjadi bermanfaat atau tidak bermanfaat tergantung cara manusia dalam memperoleh informasi sehingga menjadi informasi yang efektif dan efisien.

\section{Literasi Informasi Interpreting (menafsirkan)}

Tabel 3. Hasil Kuesioner pada Variabel Interpreting

\begin{tabular}{clc}
\hline \multirow{2}{*}{ No. } & \multicolumn{1}{c}{ Pertanyaan } & \multirow{2}{*}{ Skor (\%) } \\
\cline { 2 - 3 } 12. & Saya dapat menentukan informasi yang berkaitan dengan materi mata pelajaran geografi & $76,41 \%$ \\
13. & Saya dapat membedakan informasi yang berupa fakta, opini, dan hoax (palsu) & $77,31 \%$ \\
14. & Saya dapat mengurutkan informasi dalam urutan logis & $69,55 \%$ \\
15. & Saya dapat memahami informasi yang disampaikan berupa gambar, tabel, diagram, dan & $73,73 \%$ \\
& ilustrasi & \\
16. & Saya dapat memilih informasi sesuai kebutuhan saya & $81,79 \%$
\end{tabular}




\begin{tabular}{|c|c|c|}
\hline \multirow{2}{*}{ No. } & Pertanyaan & \multirow{2}{*}{ Skor $(\%)$} \\
\hline & Interpreting (menafsirkan) & \\
\hline 17. & Saya dapat membaca secara kritis dalam menyeleksi setiap informasi & $69,85 \%$ \\
\hline 18. & Saya mampu menerjemahkan informasi yang menggunakan bahasa Inggris & $57,91 \%$ \\
\hline 19. & Saya mampu mengolah informasi menggunakan pendapat saya sendiri & $74,32 \%$ \\
\hline 20. & $\begin{array}{l}\text { Saya mampu menganalisis informasi dengan baik, sehingga tidak melenceng dari topik } \\
\text { informasi yang saya butuhkan }\end{array}$ & $74,62 \%$ \\
\hline 21. & $\begin{array}{l}\text { Saya mampu mengidentifikasi sumber informasi (primer, sekunder, dan tersier) sesuai } \\
\text { kebutuhan tugas saya }\end{array}$ & $71,34 \%$ \\
\hline 22. & Saya mengutip informasi yang relevan sesuai dengan kebutuhan saya & $77,31 \%$ \\
\hline 23. & $\begin{array}{l}\text { Saya tertarik untuk mencari dan ingin tau secara luas mengenai informasi kebutuhan saya } \\
\text { meskipun telah menyelesaikan tugas }\end{array}$ & $73,13 \%$ \\
\hline 24. & $\begin{array}{l}\text { Saya mengerti format apa yang cocok untuk tugas saya (margin, ukuran huruf, jenis huruf, } \\
\text { ukuran kertas) }\end{array}$ & $71,94 \%$ \\
\hline \multirow[t]{3}{*}{25.} & Saya selalu memperbaiki tugas saya apabila ada kesalahan dalam penyusunan tugas saya & $77,91 \%$ \\
\hline & Jumlah & $1027,12 \%$ \\
\hline & Skor Rata-Rata & $73,36 \%$ (BAIK) \\
\hline
\end{tabular}

Sumber: Hasil olahan data primer, 2020.

Kemampuan literasi informasi kedua yaitu interpreting (menafsirkan) informasi, skor tertinggi pada kompetensi ini ditunjukkan pada pertanyaan nomor 16 menyatakan bahwa siswa dapat memilih informasi sesuai kebutuhan tugasnya, dengan hasil skor $81,79 \%$ terdapat pada interval $81 \%-100 \%$ yang berada pada kategori sangat baik. Hasil pada skor tertinggi menunjukkan bahwa hampir seluruh siswa telah dapat memilah informasi sesuai kebutuhan tugas yang diberikan oleh gurunya dan tidak keluar dari tema materi yang diberikan. Skor terendah dalam kompetensi interpreting terdapat pada pertanyaan nomor 18 yaitu siswa mampu menerjemahkan informasi yang menggunakan bahasa Inggris, dengan hasil skor 57,91\% terdapat pada interval 41\% - 60\% yang berada pada kategori cukup. Hasil skor terendah menunjukkan bahwa siswa cukup mampu dalam menerjemahkan informasi yang menggunakan bahasa Inggris, hal ini perlunya peningkatan pada siswa dalam memahami dan memperdalam kemampuan bahasa asing yaitu bahasa Inggris.

Jumlah skor rata-rata pada kemampuan literasi informasi interpreting memperoleh nilai 73,36\% yang masuk dalam kategori baik. Penelitian ini sejalan dengan penelitian yang dilakukan oleh Delima (2018), yang menyatakan bahwa kemampuan literasi informasi diperlukan untuk diajarkan kepada siswa karena tidak hanya berkaitan dengan kemampuan mengakses, mengdentifikasi, menafsirkan, mengevaluasi, dan menggunakan informasi saja, namun kemampuan untuk meningkatkan kecakapan dalam kehidupan sehari-hari, selain itu kemampuan literasi informasi dalam mengidentifikasi informasi mengajarkan siswa untuk berpikir kritis terhadap informasi yang telah diperoleh. Pada penelitian yang dilakukan oleh Abrian (2017), terdapat pernyataan yang mendukung dengan hasil penelitian ini yaitu apabila ingin menjadi manusia yang berliterasi informasi dengan baik, seseorang harus dapat memposisikan informasi pada tempatnya, mengevaluasi atau menafsirkan informasi, serta mampu menggunakan informasi secara efektif.

\section{Literasi Informasi Creating New Idea (menciptakan ide baru)}

Tabel 4. Hasil Kuesioner pada Variabel Interpreting

\begin{tabular}{|c|c|c|}
\hline \multirow{2}{*}{ No. } & Pertanyaan & \multirow{2}{*}{ Skor $(\%)$} \\
\hline & Creating New Idea (menciptkan ide baru) & \\
\hline 26 & Saya menggunakan pendapat sendiri untuk menyelesaikan tugas & $72,83 \%$ \\
\hline 27 & $\begin{array}{l}\text { Saya mampu menerapkan informasi yang saya dapatkan dari materi geografi ke dalam } \\
\text { kehidupan sehari-hari saya }\end{array}$ & $67,16 \%$ \\
\hline 28 & $\begin{array}{l}\text { Saya dapat mengkombinasikan informasi baru dengan informasi yang sudah saya } \\
\text { dapatkan }\end{array}$ & $70,74 \%$ \\
\hline 29 & Saya dapat menciptakan ide baru untuk menyelesaikan tugas saya & $70,14 \%$ \\
\hline 30 & Saya selalu memiliki ide baru dalam penyelesaian tugas saya & $67,76 \%$ \\
\hline 31 & Setelah selesai menyusun artikel/tugas, saya selalu melakukan pengecekkan ulang & $79,70 \%$ \\
\hline \multirow[t]{3}{*}{32} & Setelah selesai, saya menyunting dan memperbaiki tugas saya secara mandiri & $74,32 \%$ \\
\hline & Jumlah & $502,65 \%$ \\
\hline & Skor Rata-Rata & $71,80 \%$ (BAIK) \\
\hline
\end{tabular}

Sumber: Hasil olahan data primer, 2020. 
Kemampuan literasi informasi ketiga yaitu creating new idea (menciptakan ide baru) dalam menyelesaikan tugas, skor tertinggi pada kompetensi ini ditunjukkan pada pertanyaan nomor 31 menyatakan bahwa siswa setelah usai menyusun tugas, siswa melakukan pengecekan ulang, dengan hasil skor $79,70 \%$ terdapat pada interval 61\% - 80\% yang masuk dalam ketegori baik. Hal ini menujukkan bahwa hampir seluruh siswa selalu melakukan pengecekan ulang setelah menyelesaikan tugasnya, sehingga dapat mengurangi persentase kesalahan pada pengerjaan tugas siswa dan siswa mampu memahami kesalahan pada pengerjaan tugasnya. Skor terendah pada kompetensi ini terdapat pada pertanyaan nomor 27 yaitu siswa mampu menerapkan informasi yang berkaitan dengan materi geografi dalam kehidupan sehari-hari, dengan hasil skor 67,16\% pada interval $61 \%$ - 80\% yang masuk dalam kategori baik. Skor terendah pada kompetensi ini sudah memasuki standar kompetensi literasi informasi dalam kategori baik, tetapi akan lebih baik apabila dilakukan peningkatan dalam menerapkan materi geografi kedalam kehidupan sehari-hari.

Jumlah skor rata-rata pada kemampuan literasi informasi creating new idea memperoleh nilai $71,80 \%$ yang masuk dalam kategori baik. Hasil penelitian ini sejalan dengan hasil penelitian yang dilakukan oleh (Revila, 2019), menyatakan bahwa literasi informasi bukan hanya masalah pencarian dan pengaksesan sumber informasi, akan tetapi masalah yang lebih penting yaitu cara memilih informasi yang tepat, akurat, dan sesuai informasi yang digunakan, selain itu kemampuan literasi informasi akan meningkatkan cara berpikir kritis siswa dengan menggunakan pendapat sendiri yaitu menciptakan ide baru dan menggabungkan pendapat dengan informasi yang diperoleh. Hasil penelitian ini juga sejalan dengan penelitian Delima (2018), bahwa kemampuan literasi informasi akan memberikan pembelajaran kepada masing-masing siswa untuk berpikir kritis terhadap beragam informasi yang didapatkan, sehingga siswa mampu memecahkan masalah secara mandiri serta mampu meningkatkan motivasi kepada siswa untuk belajar dan belajar lagi.

\section{Hubungan antara prospecting, interpreting, dan creating new idea}

Untuk mengetahui hubungan antara tiga kemampuan literasi informasi siswa (prospecting, interpreting dan creating new idea) maka dilakukan analisis dengan melakukan Uji Spearman Rank sebagaimana ditampilkan pada Gambar 1.

\begin{tabular}{|c|c|c|c|c|c|}
\hline \multicolumn{6}{|c|}{ Correlations } \\
\hline & & & Prospecting & Interpreting & $\begin{array}{l}\text { Creating New } \\
\text { Idea }\end{array}$ \\
\hline \multirow[t]{9}{*}{ Spearman's tho } & \multirow[t]{3}{*}{ Prospecting } & Correlation Coefficient & 1.000 & $.643^{\pi x}$ & $.613^{x^{x}}$ \\
\hline & & Sig. (2-tailed) & & .000 & .000 \\
\hline & & $N$ & 67 & 67 & 67 \\
\hline & \multirow[t]{3}{*}{ Interpreting } & Correlation Coefficient & $.643^{x \mathrm{x}}$ & 1.000 & $.639^{x^{x}}$ \\
\hline & & Sig. (2-tailed) & .000 & & .000 \\
\hline & & $N$ & 67 & 67 & 67 \\
\hline & \multirow[t]{3}{*}{ Creating New Idea } & Correlation Coefficient & $.613^{x x}$ & $.639^{\pi x}$ & 1.000 \\
\hline & & Sig. (2-tailed) & .000 & .000 & \\
\hline & & N & 67 & 67 & 67 \\
\hline
\end{tabular}

Gambar 1. Uji Korelasi Spearman Rank

(Sumber: Hasil Analsis Peneliti, 2020)

Hasil uji korelasi menggunakan uji Spearman Rank pada Gambar 1 yang diolah menggunakan SPSS, menunjukkan bahwa terdapat hubungan antar variabel penelitian yaitu kemampuan literasi informasi prospecting, interpreting, dan creating new idea dengan nilai signifikan 0,000. Tingkat kekuatan (keeratan) hubungan antar variabel dapat diperoleh angka koefisien korelasi sebesar 0,613, artinya tingkat kekuatan hubungan (korelasi) antara variabel masuk dalam kategori kuat berdasarkan pada Tabel 5 koefisien korelasi. Pada uji korelasi penelitian ini menunjukkan bahwa diperoleh nilai koefisien korelasi yang positif, yaitu 0,000 , sehingga hubungan antara variabel bersifat searah. Korelasi positif 
artinya semakin tinggi kompetensi literasi informasi, maka semakin meningkatkan kemampuan literasi informasi siswa (Sanjaya et al., 2017).

Tabel 5. Koefisien Korelasi

\begin{tabular}{cc}
\hline Koefisien Korelasi & Kategori \\
\hline $0,00-0,19$ & Sangat Rendah \\
$0,20-0,39$ & Rendah \\
$0,40-0,59$ & Sedang \\
$0,60-0,79$ & Kuat \\
$0,80-1,00$ & Sangat Kuat \\
\hline
\end{tabular}

Sumber: Sugiyono, 2018.

Berdasarkan jumlah skor rata-rata keseluruhan, disimpulkan bahwa tingkat kemampuan literasi informasi siswa yaitu prospecting, interpreting, dan creating new idea dengan masing-masing nilai masuk ke dalam kategori baik. Hasil akhir pada jumlah skor rata-rata keseluruhan pada Tabel 6 kemampuan kompetensi literasi informasi siswa menunjukkan skor yaitu 73,91\% sesuai kriteria interpretasi skor masuk dalam kategori baik pada interval 61\% - 80\%, sehingga dapat disimpulkan bahwa tingkat kemampuan literasi informasi siswa sudah baik, namun terdapat salah satu butir soal yaitu pada Tabel 3 terdapat nomor 18 dengan pertanyaan saya mampu menerjemahkan informasi yang menggunakan bahasa Inggris dengan skor 57,91\% yang masuk ke dalam kategori cukup. Pada butir soal ini siswa cukup dalam menguasai informasi yang menggunakan bahasa Inggris, meskipun cukup namun pada butir soal ini menunjukkan bahwa kemampuan siswa dalam menerjemahkan informasi yang menggunakan bahasa Inggris memiliki angka paling rendah dibandingkan dengan butir soal lainnya, sehingga perlunya siswa dalam meningkatkan kemampuan literasi informasi pada butir soal nomor 18 .

Tabel 6. Rekapitulasi Skor Rata-Rata Variabel Penelitian

\begin{tabular}{|c|c|c|}
\hline No. & Skor Rata-Rata Variabel & Skor $(\%)$ \\
\hline 1 & Prospecting (Mencari Informasi) & $835,46: 11=75,95 \%$ (BAIK) \\
\hline 2 & Interpreting (Menafsirkan Informasi) & $1027,12: 14=73,36 \%(\mathrm{BAIK})$ \\
\hline 3 & Creating New Idea (Menciptakan Ide Baru) & $502,65: 7=71,80 \%(\mathrm{BAIK})$ \\
\hline & $\begin{array}{c}\text { Jumlah Skor Rata-Rata } \\
\text { Keseluruhan Variabel }\end{array}$ & $2365,23: 32=73,91 \%$ (BAIK) \\
\hline
\end{tabular}

Sumber: Hasil Analsis Peneliti, 2020.

Hubungan antara ketiga kemampuan literasi informasi siswa menunjukkan jumlah skor rata-rata keseluruhan masuk dalam kategori baik. Hal tersebut didasarkan pada pertanyaan kuesioner yang telah dijawab oleh siswa sesuai dengan yang mereka alami. Hal ini menunjukkan bahwa ke tiga kemampuan literasi informasi siswa baik kemampuan prospecting, interpreting, dan creating new idea sudah baik. Siswa telah memahami dalam mencari, menafsirkan, dan menciptakan ide baru pada beragam informasi selama pembelajaran daring pada mata pelajaran geografi.

Berdasarkan hasil penelitian kemampuan literasi informasi siswa termasuk dalam kategori baik, artinya bahwa siswa mampu memperoleh informasi yang akurat dan mengikuti perkembangan teknologi informasi dengan baik. Hasil penelitian ini sejalan dengan pernyataan oleh Abrian (2017) yang mendukung bahwa kemampuan dalam penguasaan literasi informasi sangat dibutuhkan dalam era globalisasi saat ini, tujuannya supaya pencari informasi mampu menggunakan informasi dan teknologi komunikasi dengan baik. Penguasaan literasi informasi siswa bertujuan supaya siswa mampu menjadi individu yang berliterasi informasi dengan baik dan siswa dapat menyelesaikan tugasnya dengan baik, sesuai dengan pernyataan oleh Hasugian (2008), bahwa penguasaan literasi informasi tidak hanya bertujuan untuk menjadikan siswa sebagai individu yang mampu berliterasi informasi, namun siswa juga harus mampu menyelesaikan tugasnya dengan baik, serta pembekalan dengan pemahaman mendalam 
diperlukan siswa karena siswalah yang nantinya akan mengajarkan dan memberikan pembelajaran terhadap lingkungannya.

Berdasarkan pembahasan pada ketiga kemampuan literasi informasi di atas, diketahui bahwa hubungan antara ketiga kemampuan literasi informasi masuk dalam kategori baik berkaitan dengan proses siswa dalam memperoleh informasi untuk menyelesaikan tugasnya, namun tidak semua kompetensi literasi informasi memiliki nilai persentase yang sama, sehingga mengikuti masing-masing kemampuan siswa dalam menyikapi saat memperoleh informasi dengan baik. Berdasarkan data persentase siswa, masing-masing kompetensi literasi informasi memiliki kategori baik, namun pada kompetensi interpreting siswa memperoleh skor terendah dengan kategori cukup. Hal ini perlunya meningkatkan kemampuan siswa dalam menafsirkan informasi, sehingga menjadi lebih baik.

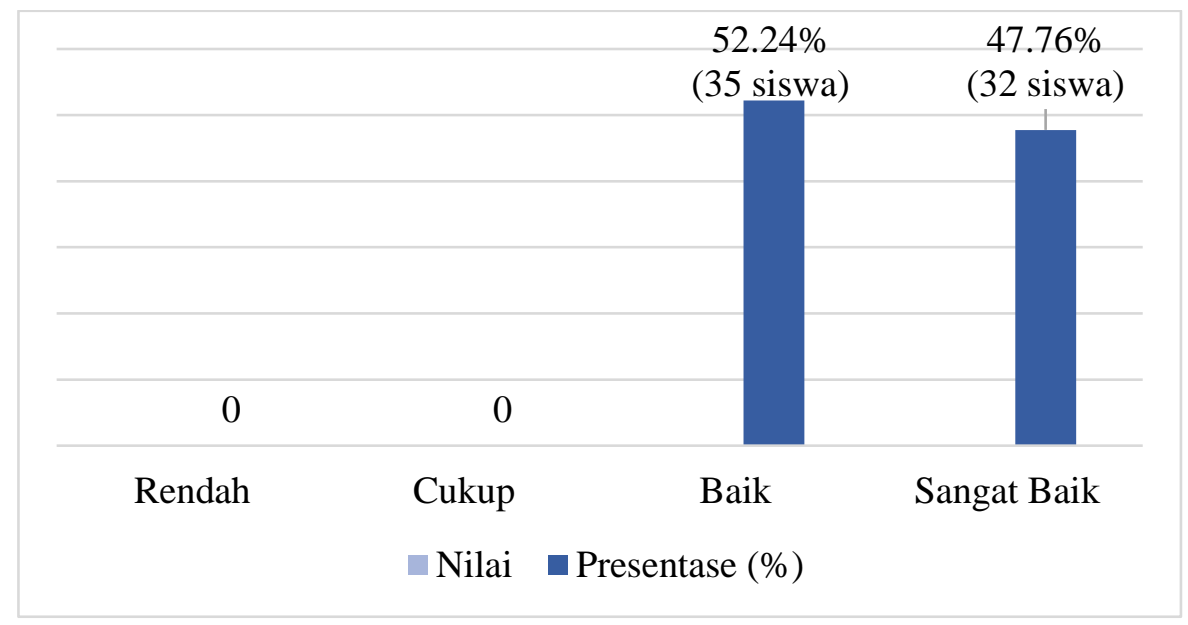

Gambar 2. Diagram Tingkat Kemampuan Literasi Informasi Siswa

(Sumber: Hasil Analsis Peneliti, 2020)

Tingkat kemampuan literasi informasi siswa kelas XI IPS dapat dilihat pada Gambar 2. Diagram pada pada gambar tersebut menunjukkan kemampuan literasi informasi siswa paling tinggi menduduki pada kategori baik dengan persentase 52,24\% yang meliputi 35 orang siswa. Selanjutnya diagram batang tersebut menunjukkan kategori sangat baik dengan persentase 47,76\% yang meliputi 32 orang siswa dari total sampel penelitian yang berjumlah 67 siswa. Sementara itu pada kategori rendah dan kategori cukup tidak ada responden (siswa) yang masuk dalam kategori tersebut.

\section{SIMPULAN}

Berdasarkan hasil analisis keseluruhan data dalam penelitian ini dapat disimpulkan bahwa kemampuan literasi informasi siswa di MAN 1 Karanganyar berada dalam kategori baik (52,24\%). Kemampuan literasi informasi pada variabel prospecting (pencarian) informasi memiliki skor 75,95\% (baik). Kemampuan literasi informasi pada variabel interpreting (menafsirkan) siswa memiliki skor $73,36 \%$ (baik). Kemampuan literasi informasi pada variabel creating new idea (menciptakan ide baru) siswa memiliki skor $71,80 \%$ (baik). Hubungan antara ketiga kemampuan literasi informasi yang telah diolah menggunakan uji korelasi Spearman Rank menunjukkan hubungan antar variabel dengan nilai signifikan 0,000. Tingkat kekuatan (keeratan) hubungan antar variabel dapat diperoleh angka koefisien korelasi sebesar 0,613, artinya tingkat kekuatan hubungan (korelasi) antara variabel masuk dalam kategori kuat. Pada uji korelasi penelitian ini menunjukkan bahwa diperoleh nilai koefisien korelasi yang positif, yaitu 0,000 , sehingga hubungan antara variabel bersifat searah. Korelasi positif artinya semakin tinggi kompetensi literasi informasi, maka semakin meningkatkan kemampuan literasi informasi siswa.

\section{DAFTAR PUSTAKA}

Abrian, B. Y. (2017). Kompetensi Literasi Informasi di Kalangan Mahasiswa Strata Satu Universitas Airlangga (Doctoral dissertation, Universitas Airlangga). 
Animar, \& Wulandya, S. A. (2020). Studi Dampak Covid-19 Terhadap Hasil Belajar Geografi di SMA Negeri 1 Sikur. Geodika: Jurnal Kajian Ilmu Dan Pendidikan Geografi, 4(2), 231-239.

Arifa, F. N. (2020). Tantangan Pelaksanaan Kebijakan Belajar dari Rumah dalam Masa Darurat Covid19. Info Singkat, 12(7), 13-18.

Cara, M. Di, \& Chatani, K. (2019). Pembelajaran Jarak Jauh Berbasis Teknologi Dan Digital di Bidang TVET.

Delima, I. (2018). Peran Guru dalam Penerapan Literasi Informasi Siswa pada Mata Pelajaran bahasa Indonesia di SMK Satria Srengseng, Jakarta Barat Tabun Pelajaran 2018/2019. (Bachelor's thesis, Jakarta: Fakultas Ilmu Tarbiyah dan Keguruan UIN Syarif Hidayatullah).

Donmoyer, R. (2008). Quantitative Research. A Sage Reference Publication. http://sk.sagepub.com/reference/research/n361.xml.

Hasugian, J. (2008). Urgensi Literasi Informasi dalam Kurikulum Berbasis Kompetensi di Perguruan Tinggi. Pustaha: Jurnal Studi Perpustakaan dan Informasi, 4(2), 34-44.

Kemenristekdikti, T. (2017). Buku Panduan; Pengisian Survei Pembelajaran dalam Jaringan. Jakarta: Kemenristekdikti.

Khoirudin, A., Setyawati, R. D., \& Nursyahida, F. (2017). Profil Kemampuan Literasi Matematika Siswa Berkemampuan Matematis Rendah dalam Menyelesaikan Soal Berbentuk PISA. Aksioma, 8(2), 33-39.

KPAI. (2020). Lawan Covid -19 dengan Jarak Sosial. https://www.kpai.go.id/berita/lawan-covid-19dengan-jarak-sosial.

Lau, J. (2006). Guidelines on Information Literacy for Lifelong Learning. Retrieved October, 4-60. http://www.jesuslau.com/docs/publicaciones/doc2/Iflaguidelines.pdf.

Mustofa, M. I., Chodzirin, M., Sayekti, L., \& Fauzan, R. (2019). Formulasi Model Perkuliahan Daring Sebagai Upaya Menekan Disparitas Kualitas Perguruan Tinggi. Walisongo Journal of Information Technology, 1(2), 151.

Revila, S. (2019). Hubungan antara Kemampuan Literasi Informasi dan Model Perilaku Pencarian Informasi dalam Program Buku Bergulir Masyarakat Desa Saok Laweh. UIN Sunan Kalijaga.

Riani, N. (2017). Model Perilaku Pencarian Informasi Guna Memenuhi Kebutuhan Informasi (Studi Literatur). Publication Library and Information Science, 1(2), 14-19.

Riduwan, \& Sunarto. (2011). Pengantar Statitiska untuk Penelitian Pendidikan, Sosial, Ekonomi, Komunikasi, dan Bisnis. Bandung: Alfabeta.

Sanjaya, I. W., Sujana, I. W., \& Suniasih, N. W. (2017). Korelasi antara Berpikir Kreatif dengan Kemampuan Pemecahan Masalah Kompetensi Inti Pengetahuan IPS Kelas V. E-Journal PGSD Universitas Pendidikan Ganesha, 5(2), 1-10.

Sartohadi, J., Suratman, J., \& Dewi, N. I. S. (2012). Pengantar Geografi Tanah. Yogyakarta: Pustaka Pelajar.

Sholeh, M. (2007). Perencanaan Pembelajaran Mata Pelajaran Geografi Tingkat SMA Dalam Konteks KTSP. Jurnal Geografi FIS Unnes, 4(2), 129-137.

Sinurat, Y. C. Z., \& Amtarina, R. (2017). Pola Keterampilan Literasi Informasi dalam Proses Pembelajaran Problem-Based Learning pada Mahasiswa di Fakultas Kedokteran Universitas Riau. JOM FK, 4(2).

Sugiyono. (2018). Metode Penelitian Pendidikan (Pendekatan Kuantitatif, Kualitatif, dan R\&D). Bandung: Alfabet.

Suharto, A. (2014). Kemampuan Literasi Informasi Pemustaka dalam Mengakses Informasi: Studi Kasus di Direktorat Perpustakaan Universitas Islam Indonesia. Jurnal Perpustakaan, 5(1), 10-20. 
Treyani, M. (2017). Mengukur Kemampuan Literasi Informasi Siswa SMAN 2 Tangerang Selatan Menggunakan Empowering 8 pada Program Kelas Percepatan. UIN Syarif Hidayatullah. 